\title{
PENGGUNAAN LEGO SEBAGAI ALTERNATIF PENANAMAN PENDIDIKAN KARAKTER DALAM MEMAHAMKAN KONSEP PENGURANGAN BILANGAN ASLI
}

\author{
Rusmini \\ SD Negeri Krejengan Kabupaten Probolinggo \\ rusmini19670426@gmail.com
}

\begin{abstract}
Abstrak
Mata pelajaran matematika, tanpa disadari seringkali mengecohkan guru dalam penanaman pendidikan berkarakter. Tidak jarang dalam proses pembelajaran matematika, guru memberikan penanaman karakter yang buruk. Sebut saja dalam pengurangan bilangan asli. Sering kali guru menggunakan kata 'pinjam'. Padahal, dia tidak pernah mengembalikan pinjamannya. Maka tujuan dari penelitian yang dilakukan dengan metode penelitian tindakan kelas ini adalah untuk memperbaiki proses pembelajaran tersebut agar tidak lagi menanamkan karakter yang buruk. Peneliti menggunakan media lego sebagai model pencacah dalam menanamkan konsep pengurangan bilangan asli. Hasil penelitian diperoleh bahwa dengan menggunakan media lego, siswa dapat mengurangi bilangan asli tanpa melakukan kesalahan konsep dan hasil belajar yang diperoleh dalam ketuntasan klasikal adalah 84,6\%. Melalui pembelajaran ini, penanaman karakter yang buruk pun dapat dihilangkan.
\end{abstract}

Kata kunci: lego, bilangan asli, pendidikan berkarakter

\begin{abstract}
Mathematics subjects, often unknowingly, clash the teacher in instilling character education. Not infrequently, in the process of learning mathematics, the teacher gives a bad character investment. Call it in the subtraction of natural numbers. Often teachers use the word 'borrow'. In fact, he never returned the loan. Then the purpose of the research conducted with this classroom action research method is to improve the learning process so that it no longer instills bad character. The researcher uses lego media as a model of the enumerator in instilling the concept of subtracting natural numbers. The results obtained that by using lego media, students can reduce natural numbers without making mistakes in concepts and learning outcomes obtained in classical completeness is $84.6 \%$. Through this learning, even the cultivation of bad characters can be eliminated.
\end{abstract}

Keywords: lego, natural numbers, character education

\section{PENDAHULUAN}

Pengurangan bilangan asli merupakan suatu pembelajaran yang mengecohkan. Guru sering kali terjebak melakukan kesalahan konsep dalam 


\section{Rusmini}

Penggunaan Lego sebagai Alternatif Penanaman Pendidikan Karakter dalam Memahamkan Konsep Pengurangan Bilangan Asli

pembelajaran ini. Sebut saja pada pengurangan bilangan 24-17. Pada praktiknya, tidak sedikit guru mengajarkan kepada siswa bahwa untuk menyelesaikan pengurangan tersebut adalah dengan mengatakan bahwa empat dikurangi tujuh, kerena tidak bisa maka empat meminjam pada dua. Memang, dengan menggunakan cara tersebut, kita akan mendapatan jawaban dengan mudah. Hal yang tidak pernah terpikirkan oleh guru adalah bahwa pembelajaran tersebut menanamkan karakter yang buruk kepada siswa. Cara menghitung tersebut menanamkan sebuah karakter bahwa sesuatu yang dipinjam tidak perlu dikembalikan karena empat tidak pernah mengembalikan pinjamannya.

Padahal, dalam abad 21 ini pendidikan karakter merupakan suatu hal yang utama. Seharusnya seluruh kegiatan belajar mengajar dapat menyisipkan pendidikan karakter, bukan justru mengacaukannya. Pada abad ini, dunia pendidikan merupakan lini terdepan dalam meningkatkan karakter siswa. Generasi penerus harus mampu beradaptasi dengan cepat dan melakukan penyesuaian dengan perkembangan yang dimiliki di abad 21 . Zulhijrah (2015) menyebutkan pendidikan karakter merupakan upaya yang dirancang dan dilaksanakan secara sistematis untuk membantu siswa memahami nilai-nilai perilaku manusia yang berhubungan dengan Tuhan Yang Maha Esa, diri sendiri, sesama manusia, lingkungan, dan kebangsaan yang terwujud dalam pikiran, sikap, perasaan, perkataan, dan perbuatan berdasarkan norma-norma agama, hukum, tata krama, budaya, dan adat istiadat.

Tantangan pada dunia pendidikan dalam menghadapi industri 4 adalah penanaman nilai pendidikan yang perlu dikembangkan (Syamsuar dan Reflianto, 2018). Program penguatan pendidikan karakter merupakan salah satu program yang bisa mengantisipasi pesatnya perkembangan teknologi dan informasi di era Revolusi Industri 4.0. Pesatnya perkembangan teknologi dan informasi ini menjadi perhatian serius bagi semua pihak, terutama untuk pengembangan karakter anak sebagai generasi penerus bangsa. Pendidikan karakter merupakan filter bagi generasi penerus agar dapat menyikapi secara bijak perkembangan teknologi dan informasi saat ini. Penguatan pendidikan karakter merupakan upaya yang dilakukan pemerintah, dalam hal ini Kemendikbud untuk pendidikan moral dan pendidikan akhlak yang bertujuan membentuk pribadi anak yang lebih baik dan selalu siap dalam setiap perubahan.

Pendidikan karakter di sekolah hendaknya tidak hanya dilakukan dalam mata pelajaran agama, tapi pada seluruh mata pelajaran yang ada. Bahkan juga pada semua tindakan di luar maupun di dalam pembelajaran. Supiana dan Sugiharto (2017) menyebutkan fenomena merosotnya karakter 
Rusmini

Penggunaan Lego sebagai Alternatif Penanaman Pendidikan Karakter dalam Memahamkan Konsep Pengurangan Bilangan Asli

berbangsa di tanah air dapat disebabkan lemahnya pendidikan karakter dalam meneruskan nilai-nilai kebangsaan pada saat alih generasi.

\section{METODE PENELITIAN}

Penelitian diterapkan dengan menggunakan metode Penelitian Tindakan Kelas (PTK). Pemilihan metode ini disesuaikan dengan tujuan PTK, yaitu dapat memberikan nilai tambah dan masukan dengan tujuan perbaikan mutu dan kualitas pendidikan di kelas/sekolah (Mulia dan Suwarno, 2016). Kemmis dan Mc. Taggart (dalam Yahya, Dwi Septiwiharti, dan Imran: 2013) menyatakan PTK adalah studi yang dilakukan untuk memperbaiki diri sendiri, pengalaman kerja sendiri yang dilaksanakan secara sistematis, terencana, dan dengan sikap mawas.

Penelitian dilaksanakan dalam proses berdaur (cyclical) yang terdiri dari empat tahapan, yaitu planning, action, observation/evaluation, dan reflection. Penelitian dilaksanakan pada semester genap 2018/2019 pada kelas 1 siswa SD Negeri Krejengan.

Teknik pengumpulan data dilakukan dengan tes hasil belajar yang diberikan pada akhir tindakan, wawancara, dan observasi. Penelitian dilakukan bersiklus dengan kriteria siklus dinyatakan berhasil dan dihentikan apabila sudah tidak lagi ditemukan kesalahan konsep pengurangan bilangan asli pada lembar jawaban tes hasil belajar siswa maupun hasil wawancara setelah tindakan. Selain itu, ketuntasan belajar secara klasikalnya telah mencapai $\geq 75 \%$ dengan merujuk pada kurikulum di SD Negeri Krejengan.

\section{HASIL DAN PEMBAHASAN}

Pendidikan karakter merupakan upaya-upaya yang dirancang dan dilaksanakan secara sistematis untuk membantu siswa memahami nilai-nilai perilaku manusia yang berhubungan dengan Tuhan Yang Maha Esa, diri sendiri, sesama manusia, lingkungan, dan kebangsaan yang terwujud dalam pikiran, sikap, perasaan, perkataan, dan perbuatan berdasarkan normanorma agama, hukum, tata krama, budaya, dan adat istiadat (Wiliandani, dkk. 2016). Sedangkan menurut Raharjo (2010), "Pendidikan karakter adalah suatu proses pendidikan secara holistic yang menghubungkan dimensi moral dengan ranah sosial dalam kehidupan siswa sebagai fondasi bagi terbentuknya generasi yang berkualitas yang mampu hidup mandiri dan memiliki suatu kebenaran yang dapat dipertanggung jawabkan."

Manitikberatkan pada dua pendapat tersebut, maka pendidikan karakter dalam penelitian ini diartikan sebagai suatu usaha yang sengaja dilakukan untuk menanamkan kecerdasan dalam berpikir dan diamalkan 


\section{Rusmini}

Penggunaan Lego sebagai Alternatif Penanaman Pendidikan Karakter dalam Memahamkan Konsep Pengurangan Bilangan Asli

dalam bentuk sikap dan perilaku yang sesuai dengan nilai-nilai luhur sehingga dapat memiliki ciri khas yang mengakar pada kepribadian individu tersebut. Oleh karena itu, penanaman pendidikan karakter tidak hanya diberikan secara teori saja melainkan harus dilakukan praktik dengan memberikan contoh teladan serta pembiasaan dalam lingkungan sekolah, keluarga maupun bermasyarakat.

Salah satu praktik nyata dalam mata pelajaran matematika adalah dengan memberikan pengajaran yang memberikan cerminan kepribadian yang baik. Hal yang diusung untuk diubah dalam pembelajaran dengan menggunakan media lego ini adalah menghilangkan bentuk 'pinjam' yang tidak pernah dikembalikan. Alasan digunakannya media dalam pembelajaran matematika kelas 1 SD adalah karena kegiatan membangun pemahaman angka dan bilangan yang sesuai dengan karakteristik siswa dalam pembelajaran memerlukan media (Purnama, Irawan, Sa'dijah, 2017).

Sesuai dengan prosedur PTK bahwa penelitian dilakukan dengan proses berdaur yang terdiri dari empat tahapan yaitu planning, action, observation/evaluation, dan reflection. Hal pertama yang dilakukan peneliti adalah planning. Diawali dengan menyiapkan perangkat pembelajaran berupa RPP, LKS, lembar observasi guru dan siswa, tes hasil belajar, dan media pembelajaran berupa lego. Seluruh instrumen tersebut kemudian divalidasi.

Penggunaan lego pada pengurangan bilangan asli ini merujuk pada Model Pencacah yang diungkap Van de Walle dalam Elementary and Middle Scool Mathematics. Alasan pemilihan lego sebagai model pencacah seperti yang diungkap oleh Rohmatin (2019) bahwa lego merupakan suatu benda yang menarik, berwarna-warni, inovatif, dan sesuai dengan pola berpikir siswa kelas 1 SD yang masih berpikir konkret. Lego merupakan sejenis alat permainan bongkah plaster kecil yang terkenal di dunia, khususnya di kalangan anak-anak hingga remaja, baik laki-laki maupun perempuan (Setyani, Dita, dan Tunggadewi, 2017).

Pengurangan adalah mengurangi dari dalam himpunan (Cipta, 2018). Pembelajaran pengurangan bilangan asli dilakukan dengan cara melepaskan siswa untuk berpikir sekreatif mungkin, bagaimana menyelesaikan pengurangan tersebut tanpa menyalahi karakter maupun konsep matematika. Guru harus mampu menjadikan matematika yang abstrak itu menjadi "nyata" dalam benak siswa sekolah dasar kelas 1 (Ningrum dan Leonard, 2014). Karena Pelajaran Matematika sebagai objek abstrak tentu saja sangat sulit untuk dapat dipahami oleh siswa SD yang belum mampu berpikir formal (Amir, 2014).

Mukrimatin, Murtono, dan Wanabuliandari (2018) menyebutkan bahwa pembelajaran matematika untuk kelas 1 SD hendaknya dapat 
Rusmini

Penggunaan Lego sebagai Alternatif Penanaman Pendidikan Karakter dalam Memahamkan Konsep Pengurangan Bilangan Asli

dibayangkan dalam pikiran siswa seolah-olah nyata yang mampu membentuk pengetahuan siswa antara pengalaman yang telah diperoleh dan penerapannya dalam kehidupan sehari-hari. Dengan demikian, siswa kelas 1 SD akan memamahi matematika sebagai pelajaran yang menyenangkan dan bukan pelajaran yang menakutkan (Frengky, 2018).

Action dilakukan dengan menerapkan pembelajaran dengan menggunakan media lego. Berikut adalah contoh langkah-langkah pembelajaran yang dilakukan dalam menanamkan konsep pengurangan bilangan asli. Misalkan pada operasi 52-18, maka nyatakan 52 dengan menggunakan lego. Ilustrasi akan tampak seperti pada gambar 1 berikut.

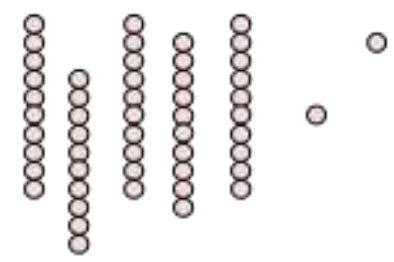

\section{Gambar 1 Ilustrasi Bilangan 52 dengan Lego}

Selanjutnya, ilustrasi bilangan 18 dengan menggunakan lego tampak seperti pada gambar 2 berikut ini.

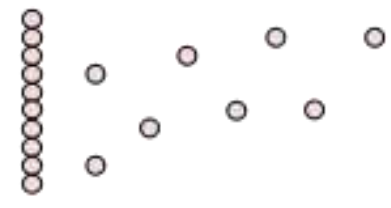

\section{Gambar 2 Ilustrasi Bilangan 18 dengan Lego}

Pada ilustrasi bilangan 52, kita hanya memiliki 2 lego kecil. Padahal, sesuai soal, kita akan menguranginya dengan 8 . Kita tidak dapat melakukannya. Tetapi, bukankah kita memiliki 5 lego panjang yang salah satunya dapat kita lepaskan pengaitnya menjadi 10 lego kecil. Maka dengan melepaskan salah satu lego panjang, ilustrasi bilangan 52 menjadi seperti gambar 3 berikut.

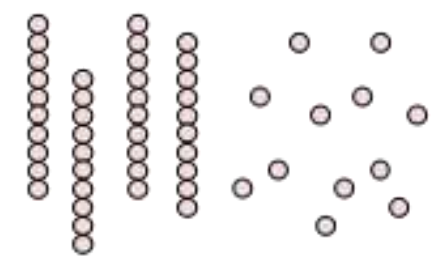

Gambar 3 Ilustrasi Bilangan 52 dengan Melepaskan Pengait Salah Satu Lego Panjang 


\section{Rusmini}

Penggunaan Lego sebagai Alternatif Penanaman Pendidikan Karakter dalam Memahamkan Konsep Pengurangan Bilangan Asli

Selanjutnya untuk 12 lego kecil dikurangi 8 lego kecil, dan 4 lego panjang dikurangi 1 lego panjang, sehingga menghasilkan seperti gambar 4 berikut.

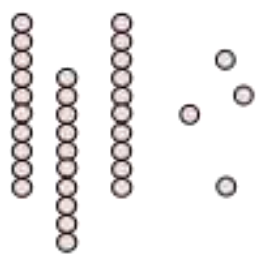

\section{Gambar 4 Ilustrasi Hasil Pengurangan Bilangan 52 dan 18}

Melalui cara tersebut, kita bisa melihat bahwa hasil pengurangannya adalah 34. Dengan demikian, maka 52-18=34. Sama sekali tidak menggunakan kata pinjam dan kegiatan pembelajaran ini tidak menyelipkan sedikit pun karakter buruk untuk siswa.

Dengan mengawalinya menggunakan model pencacah, kita dapat meminimalisir kesalahan konsep yang seringkali dilakukan siswa dalam melakukan pengurangan bersusun. Ingat, penggunaan model pencacah ini hanya untuk memahamkan siswa pada konsep pengurangan. Berikutnya, arahkan siswa untuk mendapatkan pola pada algoritma tradisional.

Observation/evaluation dari tes hasil belajar terangkum pada tabel 1 berikut.

Tabel 1 Nilai Tes Hasil Belajar

\begin{tabular}{|c|c|c|c|c|c|c|c|c|}
\hline \multirow{2}{*}{ No } & \multirow{2}{*}{ Nama } & \multicolumn{5}{|c|}{ No Soal } & \multirow{2}{*}{ Nilai } & \multirow{2}{*}{ Ket } \\
\hline & & 1 & 2 & 3 & 4 & 5 & & \\
\hline 1 & AA & B & B & $\mathrm{S}$ & B & B & 80 & $\mathrm{~T}$ \\
\hline 2 & $\mathrm{AF}$ & $B$ & $B$ & $B$ & $\mathrm{~B}$ & $\mathrm{~S}$ & 80 & $\mathrm{~T}$ \\
\hline 3 & AN & $\mathrm{B}$ & $\mathrm{B}$ & $\mathrm{B}$ & $\mathrm{B}$ & $\mathrm{B}$ & 100 & $\mathrm{~T}$ \\
\hline 4 & AY & B & $S$ & $\mathrm{~S}$ & B & B & 60 & TT \\
\hline 5 & $\mathrm{AD}$ & B & B & $B$ & B & $B$ & 100 & $\mathrm{~T}$ \\
\hline 6 & $\mathrm{AC}$ & $B$ & B & $B$ & B & $B$ & 100 & $\mathrm{~T}$ \\
\hline 7 & AW & B & $B$ & $\mathrm{~S}$ & $\mathrm{~B}$ & $B$ & 80 & $\mathrm{~T}$ \\
\hline 8 & AM & B & $\mathrm{S}$ & B & $B$ & B & 80 & $\mathrm{~T}$ \\
\hline 9 & CA & $\mathrm{S}$ & $B$ & $B$ & $\mathrm{~S}$ & $B$ & 60 & TT \\
\hline 10 & $\mathrm{HM}$ & $\mathrm{B}$ & $B$ & $\mathrm{~B}$ & $\mathrm{~S}$ & $\mathrm{~S}$ & 60 & TT \\
\hline 11 & HL & $B$ & $B$ & B & B & $B$ & 100 & $\mathrm{~T}$ \\
\hline 12 & IM & $B$ & $\mathrm{~S}$ & $\mathrm{~B}$ & $\mathrm{~B}$ & $B$ & 80 & $\mathrm{~T}$ \\
\hline 13 & IN & $B$ & $B$ & $B$ & $\mathrm{~B}$ & $B$ & 100 & $\mathrm{~T}$ \\
\hline 14 & $\mathrm{MB}$ & B & $\mathrm{B}$ & B & $\mathrm{B}$ & B & 100 & $\mathrm{~T}$ \\
\hline 15 & ML & $\mathrm{B}$ & $B$ & $B$ & B & $\mathrm{S}$ & 80 & $\mathrm{~T}$ \\
\hline 16 & $\mathrm{MA}$ & $\mathrm{B}$ & $\mathrm{B}$ & $\mathrm{B}$ & $S$ & $\mathrm{~B}$ & 80 & $\mathrm{~T}$ \\
\hline 17 & $\mathrm{MF}$ & $B$ & $B$ & $\mathrm{~S}$ & $\mathrm{~B}$ & $B$ & 80 & $\mathrm{~T}$ \\
\hline 18 & MI & B & $\mathrm{S}$ & $\mathrm{S}$ & $\mathrm{S}$ & $B$ & 40 & TT \\
\hline 19 & $\mathrm{MN}$ & $\mathrm{B}$ & $\mathrm{B}$ & $B$ & $\mathrm{~B}$ & $\mathrm{~B}$ & 100 & $\mathrm{~T}$ \\
\hline 20 & $\mathrm{MK}$ & $B$ & $B$ & $B$ & $\mathrm{~B}$ & $\mathrm{~S}$ & 80 & $\mathrm{~T}$ \\
\hline 21 & MR & B & B & B & B & B & 100 & $\mathrm{~T}$ \\
\hline
\end{tabular}


Rusmini

Penggunaan Lego sebagai Alternatif Penanaman Pendidikan Karakter dalam Memahamkan Konsep Pengurangan Bilangan Asli

\begin{tabular}{ccccccccc}
\hline 22 & NC & B & B & B & B & B & 100 & T \\
\hline 23 & RP & B & B & S & B & B & 80 & T \\
\hline 24 & RA & B & B & B & B & S & 80 & T \\
\hline 25 & SA & B & B & B & B & B & 100 & T \\
\hline 26 & SU & B & B & B & B & B & 100 & T \\
\hline
\end{tabular}

Berdasarkan reflection pada siklus pertama, dengan memperhatikan tes hasil belajar yang berisikan soal-soal pengurangan bilangan asli dalam lima butir soal, didapatkan ketuntasan belajar secara klasikalnya adalah 84,6\%. Melalui hasil wawancara, peneliti sama sekali tidak mendapati kesalahan konsep yang dilakukan oleh siswa. Maka sesuai dengan kriteria siklus yang ditentukan dalam penelitian ini, siklus satu dinyatakan berhasil dan dihentikan. Hal tersebut juga berdasar pada hasil observasi yang menunjukkan kesesuaian antara rencana yang disusun dengan praktik yang dilakukan di lapangan.

\section{KESIMPULAN DAN SARAN}

Berdasarkan hasil penelitian yang dilakukan dengan PTK maka disimpulkan bahwa pembelajaran pengurangan bilangan asli dengan menggunakan media lego dapat menanamkan pemahaman konsep matematika dengan tepat sekaligus juga memberikan pendidikan karakter yang positif. Melalui pembelajaran ini, maka perbaikan proses pembelajaran seperti yang ditujukan oleh PTK terpenuhi dengan baik. Melalui pembelajaran dengan menggunakan lego ini, guru matematika sudah tidak terkecoh lagi dengan menggunakan kata pinjam dalam melakukan pengurangan bilangan asli.

Saran peneliti kepada para guru hendaknya benar-benar memperhatikan penanaman karakter yang baik. Terutama guru matematika. Beberapa pembelajaran dalam matematika rupanya tanpa disadari memberikan karakter yang buruk bagi sisiwa.

\section{DAFTAR RUJUKAN}

Amir, Almira. (2014). Pembelajaran Matematika SD dengan Menggunakan Media Manipulatif. Forum Paedagogik, VI(1), 72-89.

Cipta, Dyah Ayu Sulistyaning. (2018). Penerapan Pendekatan Montessori untuk Menanamkan Pemahaman Konsep Bilangan Cacah pada Siswa TK Putera Zaman Malang. Jurnal Matematika dan Pembelajaran, 6(1), 30-34.

Frengky. (2018). Model Pembelajaran Matematika Siswa Kelas Satu Sekolah Dasar. Jurnal Psikologi, 35(1), 151-163.

Mukrimatin, Murtono, \& Wanabuliandari. (2018). Pemahaman Konsep Matematika Siswa Kelas V SD Negeri Rau Kedung Jepara pada Materi 
Rusmini

Penggunaan Lego sebagai Alternatif Penanaman Pendidikan Karakter dalam Memahamkan

Konsep Pengurangan Bilangan Asli

Perkalian Pecahan. Anargya: Jurnal Ilmiah Pendidikan Matematika, I(1), 67-71.

Mulia, Dini Siswani, \& Suwarno. (2016). PTK (Penelitian Tindakan Kelas) dengan Pembelajaran Berbasis Kearifan Lokal dan Penulisan Artikel Ilmiah di SD Negeri Kalisube, Banyumas. Hazanah Pendidikan: Jurnal Ilmiah Kependidikan, IX(2).

Ningrum \& Leonard. (2014). Pengembangan Desain Pembelajaran Matematika Sekolah Dasar Kelas 1. Jurnal Formatif, 4(3), 163-173.

Purnama, Irawan, Sa'dijah. (2017). Pengembangan Media Box Mengenal Bilangan dan Operasinya Bagi Siswa Kelas 1 Di Sdn Gadang 1 Kota Malang. Jurnal Kajian Pembelajaran Matematika, 1(1), 46 -51.

Raharjo. (2010). Pendidikan Karakter Sebagai Upaya Menciptakan Akhlak Mulia. Jurnal Pendidikan dan Kebudayaan, 16 (3).

Rohmatin, Titik. (2019). Media Lego Warna pada Penjumlahan Bilangan Bulat di Sekolah Dasar. Jurnal Pena Karakter, 1(2), 25-35.

Setyani, Dita, \& Tunggadewi. (2017). Penerapan Lego Bricks dalam Pembelajaran Sebagai Strategi untuk Meningkatkan Kecerdasan Matematis Siswa dalam Menghitung Bilangan Berpangkat. Fibonacci, 3(1), 53-64.

Supiana \& Rahmat Sugiharto. (2017). Pembentukan Nilai-nilai Karakter Islami Siswa Melalui Metode Pembiasaan. Educan: Jurnal Pendidikan Islam, 1(1), 89-109.

Syamsuar \& Reflianto. (2018). Pendidikan dan Tantangan Pembelajaran Berbasis Teknologi Informasi di Era Revolusi Industri 4.0. E-Teach: Jurnal Ilmiah Teknologi Pendidikan, 6(2), 1-13.

Wiliandani, A. M., Wiyono, B. B., \& Sobri, A. Y. (2016). Implementasi Pendidikan Karakter dalam Pembelajaran di Sekolah Dasar. Jurnal Pendidikan Humaniora, 4(3), 132-142.

Yahya, Dwi Septiwiharti, \& Imran. (2013). Meningkatkan Hasil Belajar Siswa Kelas IV Mata Pelajaran PKn melalui Media Kliping di SD Inpres Despot Posona Kecamatan Kasimbar. Jurnal Kreatif Tadulako, 1(3), 118-130.

Zulhijrah. (2015). Implementasi Pendidikan Karakter di Sekolah. Tadrib, 1(1), 1-19. 